\title{
No Difference Between the Effects of Supplementing With Soy Protein Versus Animal Protein on Gains in Muscle Mass and Strength in Response to Resistance Exercise
}

\author{
Mark Messina \\ Nutrition Matters, Inc. \\ Heidi Lynch \\ Point Loma Nazarene University \\ Jared M. Dickinson \\ Arizona State University \\ Katharine E. Reed \\ University of Essex
}

\begin{abstract}
Much attention has been given to determining the influence of total protein intake and protein source on gains in lean body mass (LBM) and strength in response to resistance exercise training (RET). Acute studies indicate that whey protein, likely related to its higher leucine content, stimulates muscle protein synthesis to a greater extent than proteins such as soy and casein. Less clear is the extent to which the type of protein supplemented impacts strength and LBM in long-term studies ( $\geq 6$ weeks). Therefore, a meta-analysis was conducted to compare the effect of supplementation with soy protein to animal protein supplementation on strength and LBM in response to RET. Nine studies involving 266 participants suitable for inclusion in the meta-analysis were identified. Five studies compared whey with soy protein, and four studies compared soy protein with other proteins (beef, milk, or dairy protein). Meta-analysis showed that supplementing RET with whey or soy protein resulted in significant increases in strength but found no difference between groups (bench press: $\chi^{2}=0.02, p=.90$; squat: $\chi^{2}=0.22, p=.64$ ). There was no significant effect of whey or soy alone $(n=5)$ on LBM change and no differences between groups $\left(\chi^{2}=0.00, p=.96\right)$. Strength and LBM both increased significantly in the "other protein" and the soy groups $(n=9)$, but there were no between-group differences (bench: $\chi^{2}=0.02, p=.88$; squat: $\chi^{2}=0.78, p=.38$; and LBM: $\chi^{2}=0.06, p=.80$ ). The results of this meta-analysis indicate that soy protein supplementation produces similar gains in strength and LBM in response to RET as whey protein.
\end{abstract}

Keywords: isoflavones, lean body mass, leucine, meta-analysis, plant protein

For a variety of reasons, dietary protein has gained increased research attention in recent years. Evidence shows that consuming protein in excess of the U.S. recommended dietary allowance has health benefits and that for many population groups, the recommended dietary allowance of protein $(0.8 \mathrm{~g} / \mathrm{kg}$ body weight $)$ is too

(C) 2018 The Authors. Published by Human Kinetics, Inc. This is an Open Access article distributed under the terms of the Creative Commons Attribution License CC BY 4.0, which permits unrestricted noncommercial and commercial use, distribution, and reproduction in any medium, provided the original work is properly cited, the new use includes a link to the license, and any changes are indicated. See https:// creativecommons.org/licenses/by/4.0/. This license does not cover any third-party material which may appear with permission in the article.

Messina is with Nutrition Matters, Inc., Pittsfield, MA. Lynch is with Kinesiology Dept., Point Loma Nazarene University, San Diego, CA. Dickinson is with Exercise Science and Health Promotion Program, Healthy Lifestyles Research Center, School of Nutrition and Health Promotion, Arizona State University, Phoenix, AZ. Reed is with the School of Sport, Rehabilitation and Exercise Science, University of Essex, Colchester, United Kingdom. Address author correspondence to Mark Messina at markjohnmessina@gmail.com. low (Wolfe et al., 2017). Higher protein intakes may help to prevent and/or delay the onset of sarcopenia, and because protein is more satiating than carbohydrate and fat, higher protein diets may also help with weight management (Cuenca-Sanchez et al., 2015).

In addition to the total protein intake, research has focused on the effects of different types of protein, in particular plant versus animal protein, on the risk of developing various chronic diseases (Richter et al., 2015; Shang et al., 2016a, 2016b; Sucher et al., 2017). Although western health authorities have generally called for economically advanced countries to consume a more plantbased diet for both health and environmental reasons (Springmann et al., 2016), per capita meat consumption is predicted to increase as the global population becomes wealthier (Shi et al., 2015), although animal protein will likely still be beyond the economic reach of billions of people (Speedy, 2003). Consequently, much of the world will continue to rely primarily on plants to meet their dietary protein needs.

For millions of Asians (Messina et al., 2006) and for many Western vegetarians and health-conscious individuals, soy foods are an important source of protein (Rizzo et al., 2013). Soybeans 
are not only higher in protein than other legumes but the quality of soy protein is superior to that of other plant proteins and relatively similar to that of animal proteins (Hughes et al., 2011; Rutherfurd et al., 2015). Soy protein is often considered to be the quintessential plant protein, and as such, it is often compared with animal proteins in various animal and human studies.

Although foods such as tofu, miso, and soy milk are the most popular forms of soy throughout Asia, many intervention animal studies typically rely on the use of soy protein products-such as isolated soy protein, soy protein concentrate, and soy flour and textured vegetable protein ${ }^{\circledR}$ - to evaluate the health effects of soy protein. On a dry weight basis, the protein contents range from $\sim 56 \%$ to $59 \%$ in soy flour/textured vegetable protein, $65 \%$ to $72 \%$ in soy protein concentrate, and $90 \%$ to $92 \%$ in isolated soy protein. Of these soy protein products, isolated soy protein is an especially convenient product for incorporating large amounts of soy protein into the diet and for that reason is most commonly used for experimental purposes.

Plant proteins such as soy protein may have a number of advantages over animal protein, such as lowering blood cholesterol levels (Tokede et al., 2015); however, a general view within the sports nutrition community is that animal proteins and whey protein, in particular, are more effective in building muscle in response to resistance exercise training (RET) (Devries \& Phillips, 2015; Hulmi et al., 2010; van Vliet et al., 2015). Some researchers consider whey protein to be superior to soy protein in building muscle and increasing strength, which is not surprising given the results of acute studies monitoring changes in muscle protein synthesis (MPS) over a 3- to 4-hr period. To the authors' knowledge, seven such studies (Gran et al., 2014; Luiking et al., 2011; Mitchell et al., 2015; Rittig et al., 2017; Tang et al., 2009; Wilkinson et al., 2007; Yang et al., 2012a) involving both younger (Luiking et al., 2011; Rittig et al., 2017; Tang et al., 2009; Wilkinson et al., 2007) and older men (Gran et al., 2014; Mitchell et al., 2015; Yang et al., 2012a) have compared whey to soy. Three of these studies focused on markers of MPS such as phosphorylation of ribosomal protein S6 kinase $\beta-1$ (p70S6 kinase) (Gran et al., 2014; Mitchell et al., 2015) or the mammalian/mechanistic target of rapamycin (mTOR) (Gran et al., 2014; Rittig et al., 2017), whereas three other studies did not involve an exercise component (Gran et al., 2014; Luiking et al., 2011; Rittig et al., 2017). Important to note, in two of these studies (Mitchell et al., 2015; Yang et al., 2012a), the data for whey protein were derived from previously published research (D'Souza et al., 2014; Yang et al., 2012a).

There may be a number of possible factors, such as greater systemic availability of amino acids (Devries \& Phillips, 2015), that account for the greater effect of whey protein in comparison with soy protein on MPS. However, much of the difference between the two proteins is likely attributable to the higher leucine content of whey protein (Norton et al., 2012; Tang et al., 2009). Leucine, one of the three branched-chain amino acids, has been extensively investigated for its ability to activate MPS. In particular, leucine activates MPS through the mTOR complex 1 (mTORC1) (Anthony et al., 2000) and possibly also through an mTORC1-independent process (Bolster et al., 2004). Recognition of the important role of leucine in stimulating MPS (Katsanos et al., 2006) has given rise to the "leucine threshold" hypothesis, which refers to the leucine intake required to reach a muscle intracellular leucine concentration that triggers a robust increase in MPS following protein consumption (Phillips, 2014). Once this threshold is met, further increases in leucine do not lead to further increases in the muscle anabolic response (Glynn et al., 2010).
The International Society of Sports Nutrition recommends that the postexercise meal contain as much as $3 \mathrm{~g}$ of leucine in addition to a balanced array of indispensable amino acids (IAAs) (Jäger et al., 2017). The amount of leucine required to maximally stimulate MPS may be affected by many factors including age (Burd et al., 2013; Moore et al., 2009; Witard et al., 2014) as older individuals most likely require more dietary protein and leucine to stimulate MPS than younger people (Breen \& Phillips, 2011; D'Souza et al., 2014; Glynn et al., 2010; Moore et al., 2015; Volpi et al., 1999). In theory, proteins with a higher branched-chain amino acid content will lead to greater MPS (Fouillet et al., 2002; Luiking et al., 2005). Because of the key role of leucine, adding this branched-chain amino acid to lesser amounts of total protein can stimulate MPS to a similar extent as a larger amount of protein that provides a similar amount of leucine (Churchward-Venne et al., 2014; Katsanos et al., 2006; Wilkinson et al., 2013).

Although acute studies evaluating MPS may provide valuable insight, MPS following protein supplementation and resistance exercise may last for at least $24 \mathrm{hr}$ (Burd et al., 2011). Thus, it is important to determine how protein source affects changes in strength and lean tissue accretion in long-term studies. Knowing how these metrics are affected by protein type is an important public health consideration because greater lean tissue is associated with overall health (Wolfe et al., 2017) and with the prevention of functional decline with aging (Bradlee et al., 2017). Strength may actually be a much more important barometer than muscle mass as research indicates that among older adults, low muscle strength is independently associated with elevated risk of all-cause mortality regardless of muscle mass (Li et al., 2018; Newman et al., 2006). Therefore, to determine whether supplementation with soy protein or other animal proteins differentially impacts the response to RET, a meta-analysis of long-term studies specifically comparing supplementation with soy protein to whey protein and other animal proteins on lean tissue accretion and strength in response to RET was performed. This analysis was undertaken in part to evaluate the recent conclusion by Morton et al. (2017) who showed that protein source likely plays a minor role in determining the impact of protein supplementation on gains in LBM and strength in response to RET.

\section{Materials and Methods}

\section{Criteria and Search Strategy}

The meta-analysis was carried out in accordance with the preferred reporting items for systematic reviews and meta-analyses guidelines (Moher et al., 2009). The literature search (through November 2017) was performed without date restrictions on articles published in peer-reviewed journals using Web of Science, PubMed, and Google Scholar. The following search terms were used: "soy," "whey," "protein," "animal protein," "muscle," "training," "exercise," and "lean mass." References listed in papers identified by the search and that came to the attention of the authors through other means were also considered for inclusion.

Nonhuman studies and those including participants aged less than 18 years were excluded from the meta-analysis, which was comprised of two separate comparisons: changes in muscular strength and changes in LBM. Studies could be included in one or both comparisons, but it was not required that those studies reporting strength also reported LBM or vice versa. To be included, study participants were required to undertake a RET program of at least 6 weeks in duration, training at least twice per week, prior to 
which they were randomly allocated to a nutritional supplementation protocol in which the addition of soy protein to the diet was compared with the addition of nonsoy protein. Studies were required to provide the necessary data for the calculation of effect sizes (pretraining and posttraining means and standard deviations) for outcome measures. Outcome measures were assessment of maximal muscular strength (upper body or lower body) and assessments

of LBM. Strength was measured as one-repetition maximum (in kilograms) in all studies that assessed changes in muscle strength. LBM was assessed via dual-energy X-ray absorptiometry in four studies (Candow et al., 2006; Kalman et al., 2007; Maltais et al., 2016; Volek et al., 2013), and one study each used air displacement plethysmography (Haub et al., 2002), skinfold (Denysschen et al., 2009), and hydrostatic weighing (Brown et al., 2004). Studies could be included if they provided the data necessary to calculate LBM; for example, it could be derived from body mass and measures of percentage body fat.

\section{Data Extraction}

Data extraction was performed by M.M. and K.E.R. M.M. collated all the data, and K.R. verified data accuracy and confirmed eligibility for inclusion. For each outcome measure, pre- and posttraining means and standard deviations were extracted for the soy-protein-supplemented group and control (comparator) protein group and used in the analysis. In all cases, the last available measurement was used for comparison; for example, in the study by Volek et al. (2013), changes at 3-, 6-, and 9-month periods were reported, but only the 9-month time point was used for analysis.

\section{Data Analysis}

Statistical analysis was performed in RevMan (Review Manager, version 5.3; London, UK). A fixed effects model of the inverse variance method for meta-analysis was used to analyze the data. This method assigns a proportionate weight to studies according to the magnitude of standard error and permits analysis while controlling for heterogeneity. Outcome measures of change (postintervention $[\mathrm{kg}]$ - preintervention $[\mathrm{kg}]$ ) in strength and lean mass were expressed as the standardized mean difference with $95 \%$ confidence intervals.

\section{Bias and Heterogeneity}

Within each comparison, heterogeneity using the $I^{2}$ statistic was calculated (Moher et al., 2009). It was assumed that a value of $I^{2}<25 \%$ demonstrated low heterogeneity, 25-50\% was considered moderate heterogeneity, and $75 \%$ or more demonstrated high heterogeneity. Bias was examined using funnel plots for each outcome variable. With a low number of studies, statistical tests to determine bias would likely be underpowered, so a visual inspection using a funnel plot was used.

\section{Results}

Of the 62 studies originally identified by the literature search, only nine studies met the inclusion criteria for the meta-analysis (Brown et al., 2004; Candow et al., 2006; Denysschen et al., 2009; Hartman et al., 2007; Haub et al., 2002; Kalman et al., 2007; Maltais et al., 2016; Thomson et al., 2016; Volek et al., 2013). Reasons for exclusion are shown in Figure 1. Studies reported a range of

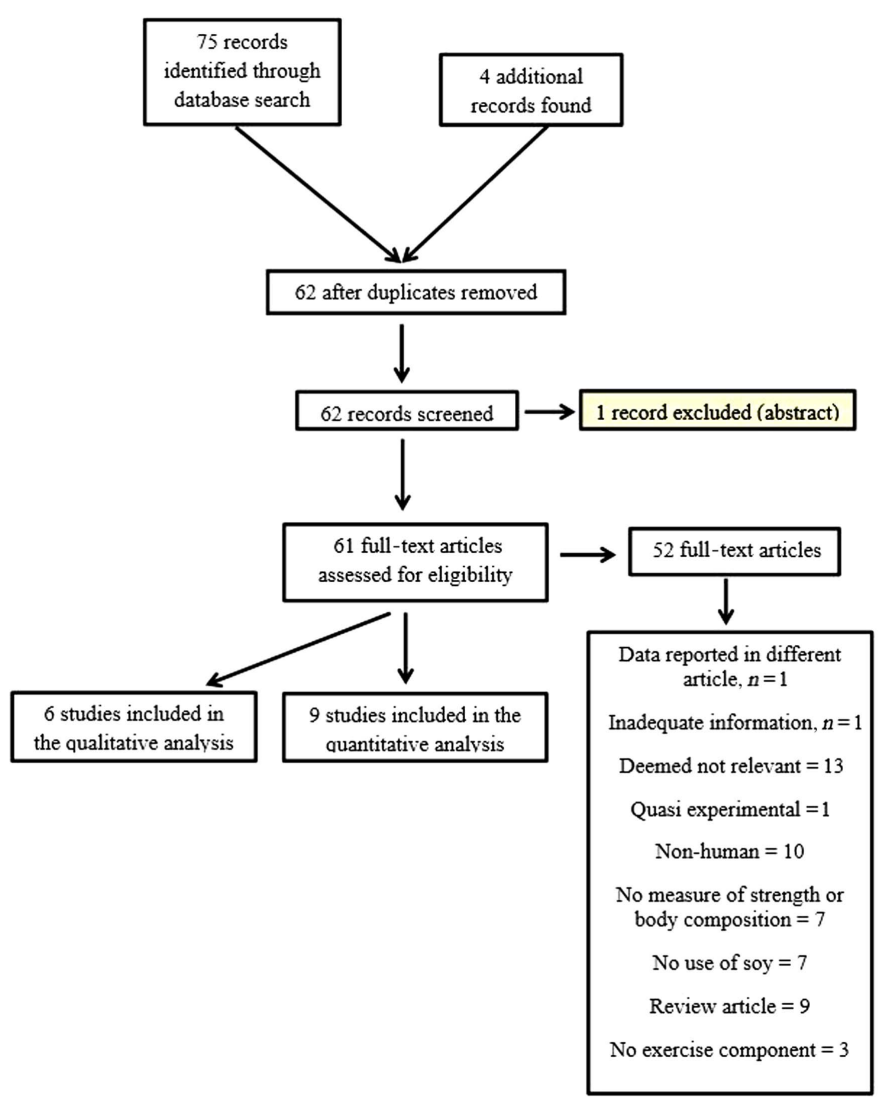

Figure 1 - Flow diagram showing outcomes of literature search and inclusion/exclusion of studies at each stage.

strength measures, so the most frequently assessed were identified and used for statistical comparisons. All studies reported bench press (upper body) or a measure of lower body strength such as squat (lower body) or incline press in kilograms. Funnel plots showed no evidence of publication bias (data not shown).

Of the nine studies included in the analysis, the comparator protein to soy was whey in five studies and beef or dairy or milk protein in four studies (Table 1). As the soy versus whey comparison is the most common and of primary interest, separate forest plots were created for this analysis. Data from 106 participants aged 18-50 years were included in the soy- versus whey-only analysis (Figures 2-4). Data from 266 individuals aged 18-70 years were included in the extended analysis (soy vs. other proteins; Figures 5-7).

With respect to prior experience with RET, in the study by Brown et al. (2004), the participants were trained weight lifters; in the study by Kalman et al. (2007), the participants included a mix of trained and untrained individuals but they were matched per group; and in the study by Haub et al. (2002), the training background of the participants was not indicated but they appeared to be untrained. In the other six studies, the participants were described as having not previously participated in RET for at least 1 year. Five of the nine studies were conducted in the United States (Brown et al., 2004; Denysschen et al., 2009; Haub et al., 2002; Kalman et al., 2007; Volek et al., 2013), three in Canada (Candow et al., 2006; Hartman et al., 2007; Maltais et al., 2016), and one in Australia (Thomson et al., 2016). The duration of these studies ranged from 6 (Candow et al., 2006) to 36 (Volek et al., 2013) 


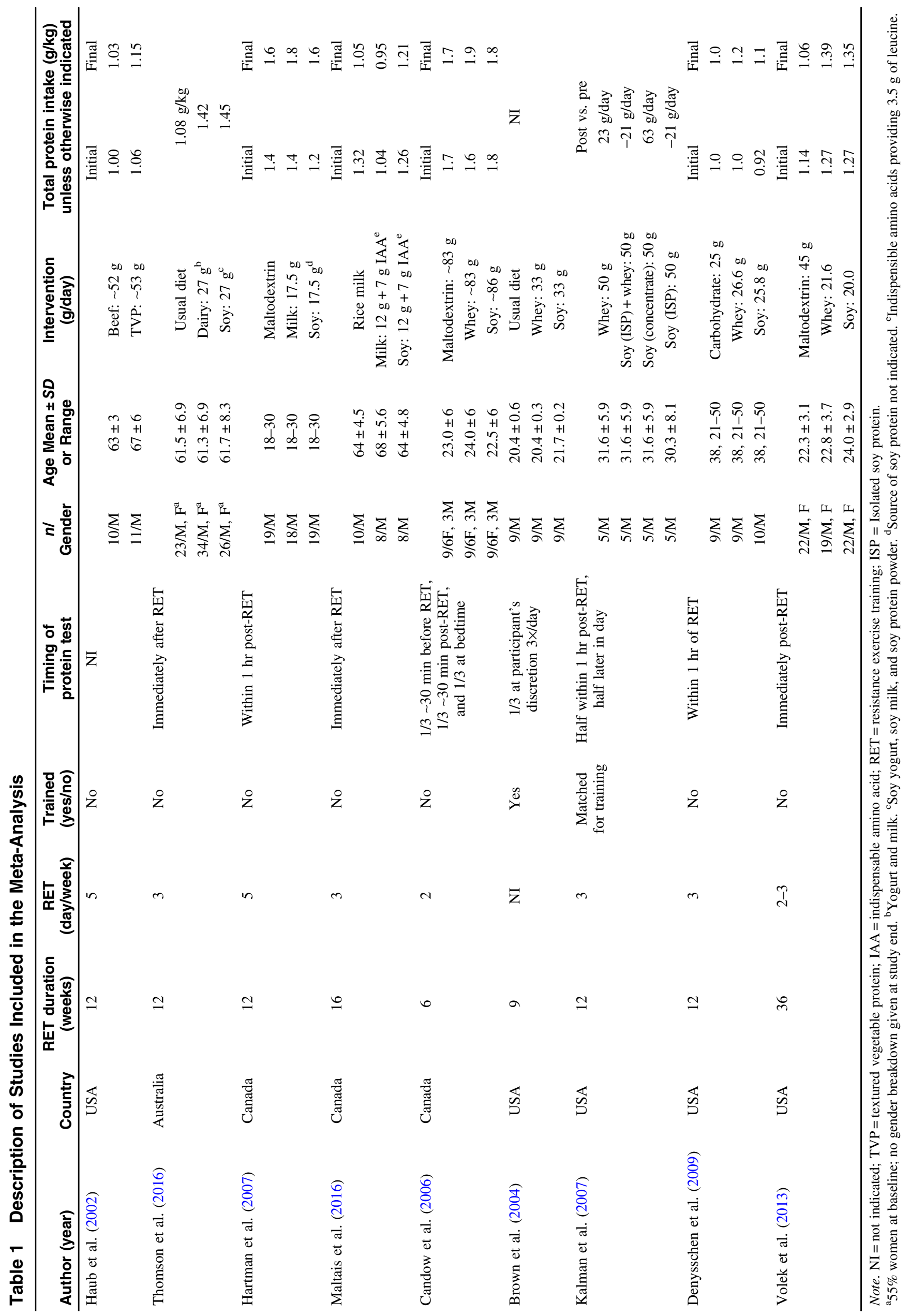




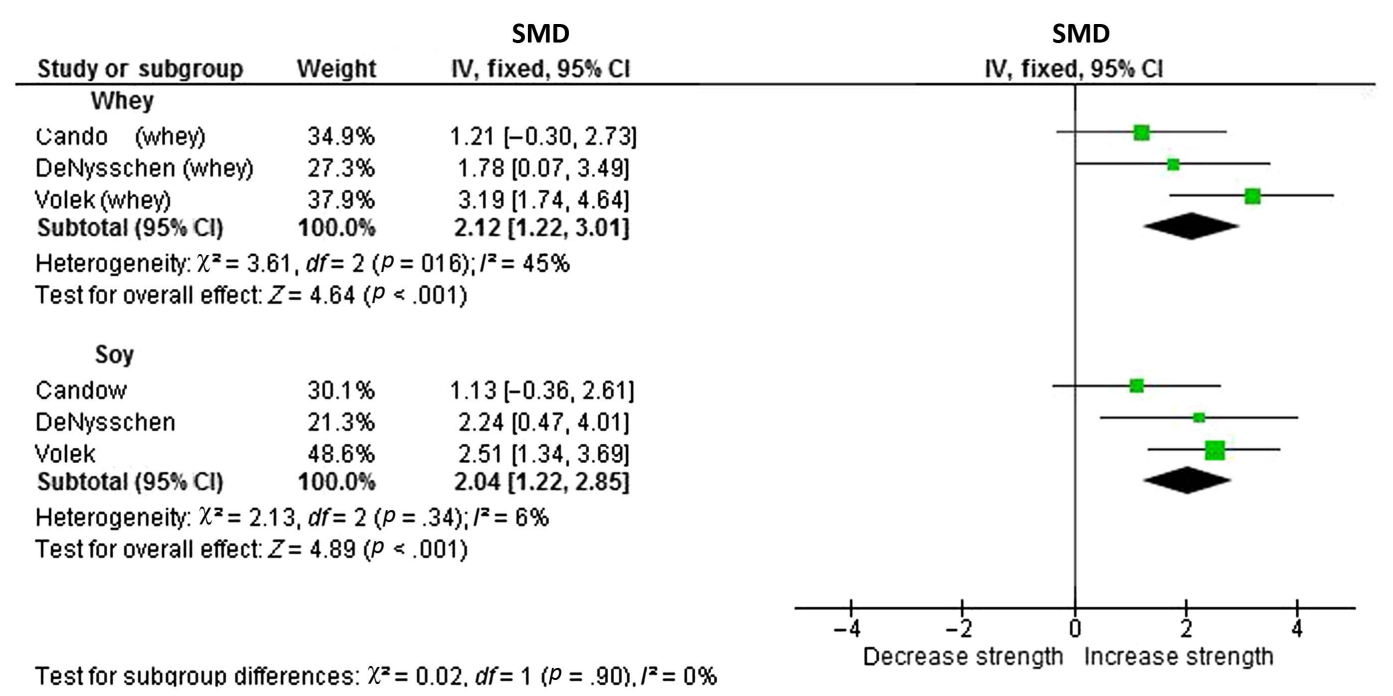

Figure 2 - Forest plot showing the effect of protein source supplementation (whey vs. soy) combined with RET, on change (SMD) in bench press strength (one-repetition maximum). Effect for each group and a comparison of change between groups $\left(\chi^{2}\right)$ are shown. RET $=$ resistance exercise training; $\mathrm{SMD}=$ standard mean difference; $\mathrm{CI}=$ confidence interval.

(mean: $13.6 \pm 8.6$ ) weeks and protein supplementation ranged from 12 (plus IAA) (Maltais et al., 2016) to 86 g/day (Candow et al., 2006). Six studies included only men (Brown et al., 2004; Denysschen et al., 2009; Hartman et al., 2007; Haub et al., 2002; Kalman et al., 2007; Maltais et al., 2016), three included both genders (Candow et al., 2006; Thomson et al., 2016; Volek et al., 2013), and three included participants who were older than 50 years of age (Haub et al., 2002; Maltais et al., 2016; Thomson et al., 2016); in one of these studies, the participants were described as sarcopenic (Maltais et al., 2016), and in another study, the dropout rate in the soy group exceeded 50\% (Thomson et al., 2016). In the study involving sarcopenic men, the milk and soy beverages were supplemented with IAA providing $3.5 \mathrm{~g}$ of leucine (Maltais et al., 2016).

\section{Whey Versus Soy Protein}

As noted, five studies compared soy protein with whey protein (Brown et al., 2004; Candow et al., 2006; Denysschen et al., 2009; Kalman et al., 2007; Volek et al., 2013). The within-study heterogeneity $\left(I^{2}\right)$ was low to moderate within each subgroup ranging from $45 \%$ to $0 \%$ (Figures 2-5).

There were significant increases in strength (one-repetition maximum), but not LBM in each subgroup as a result of the interventions. Subgroup analysis was carried out to look for differences in change in strength or lean mass according to protein type. As shown in Figure 2, there was no significant $\left(\chi^{2}=0.02, p\right.$ $=.90$ ) difference in the change in bench press one-repetition maximum in the whey versus soy subgroup comparison. There were also no significant subgroup differences between whey and

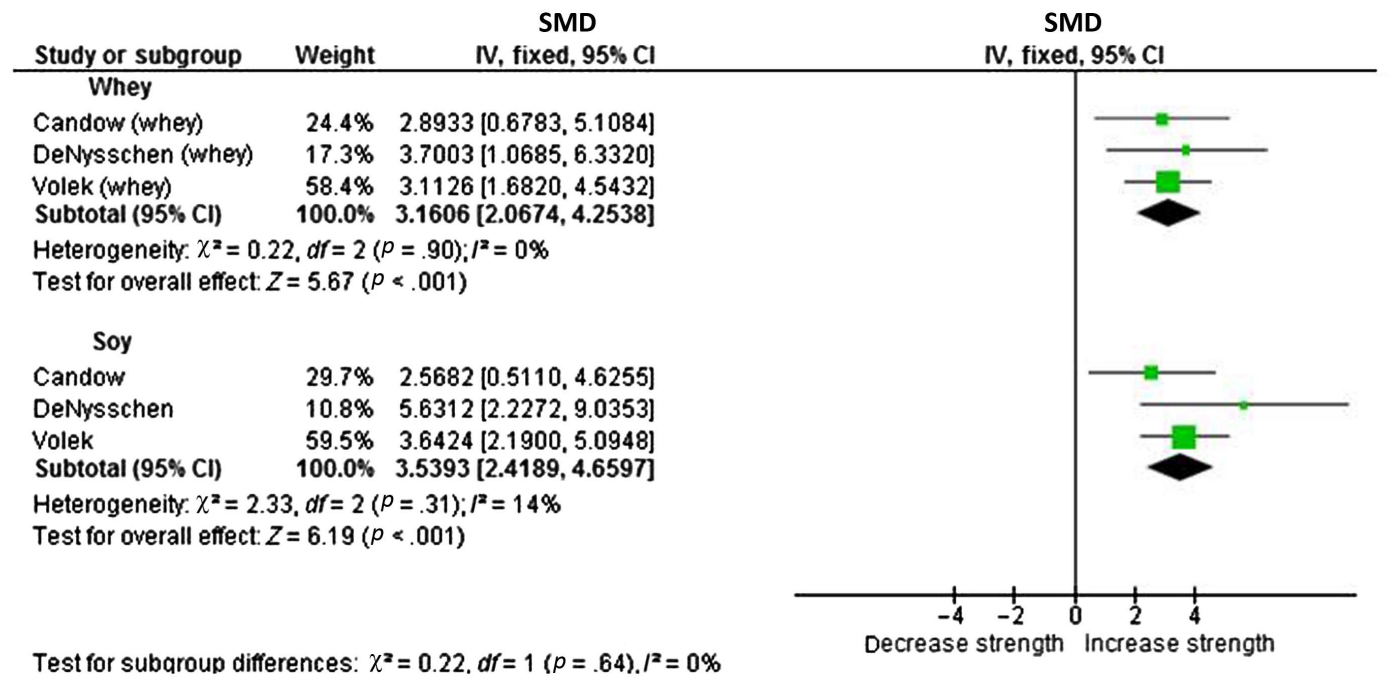

Figure 3 - Forest plot showing the effect of protein source supplementation (whey vs. soy) combined with RET, on change (SMD) in squat/leg press strength (one-repetition maximum). Effect for each group and a comparison of change between groups $\left(\chi^{2}\right)$ are shown. RET $=$ resistance exercise training; $\mathrm{SMD}=$ standard mean difference; $\mathrm{CI}=$ confidence interval. 


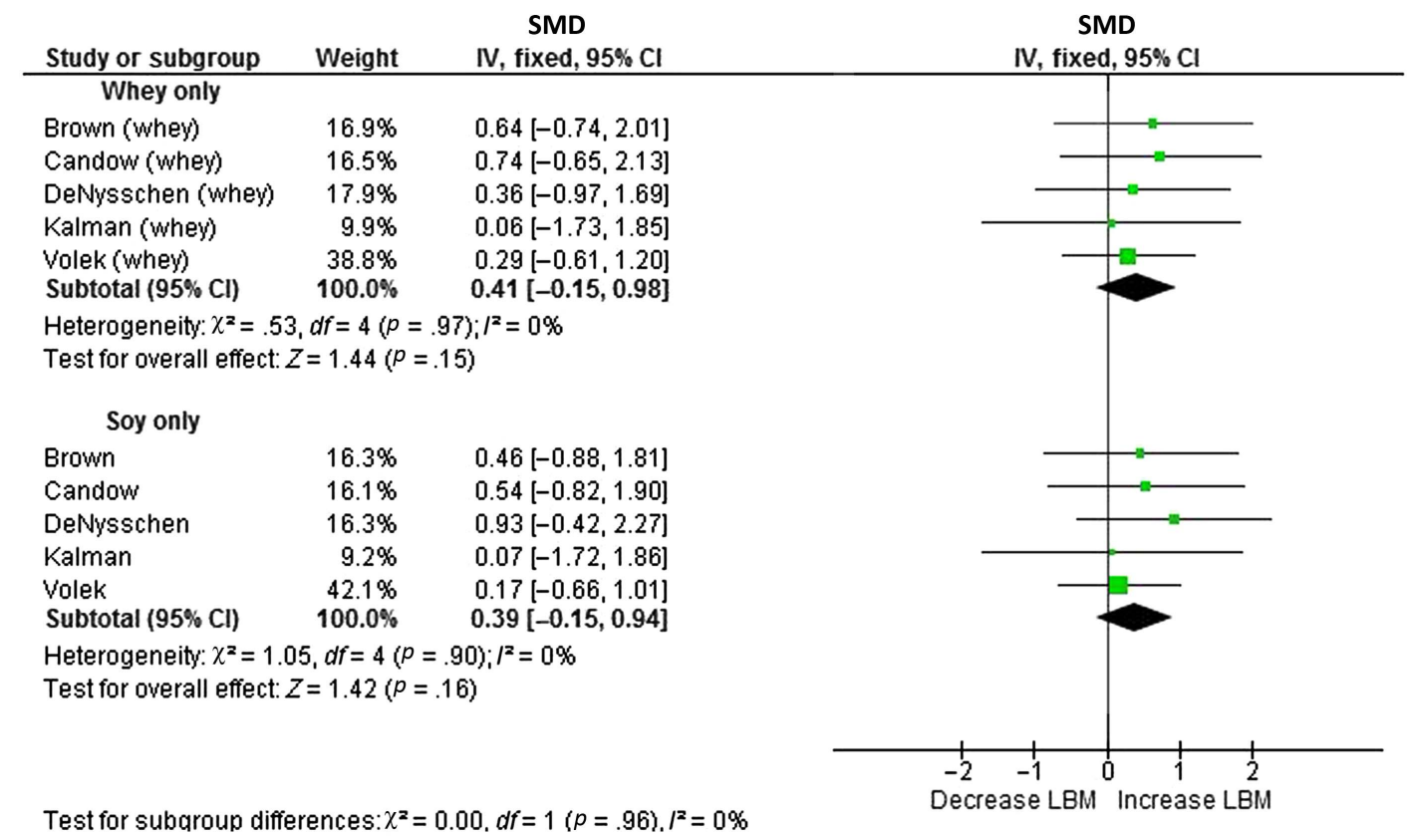

Figure 4 - Forest plot showing the effect of protein source supplementation (whey vs. soy) combined with RET, on change (SMD) in LBM. Effect for each group and a comparison of change between groups $\left(\chi^{2}\right)$ are shown. LBM = lean body mass; RET = resistance exercise training; SMD = standard mean difference; $\mathrm{CI}=$ confidence interval.

soy groups for the change in squat strength (Figure $3 ; \chi^{2}=0.22$, $p=.64$ ) or for increases in LBM (Figure $4 ; \chi^{2}=0.00, p=.96$ ).

\section{Other Proteins Versus Soy Protein}

Nine studies compared soy protein versus all other proteins (whey, beef, and dairy) (Brown et al., 2004; Candow et al., 2006; Denysschen et al., 2009; Hartman et al., 2007; Haub et al., 2002; Kalman et al., 2007; Maltais et al., 2016; Thomson et al., 2016; Volek et al., 2013). Again, within-study heterogeneity $\left(I^{2}\right)$ was low to moderate ranging between $88 \%$ and $0 \%$.

There were significant increases in both strength and LBM in each subgroup as a result of the interventions. None of the subgroup comparisons resulted in significant differences between the soy and the other proteins groups. These between-subgroup comparisons were bench press (Figure $5 ; \chi^{2}=0.02, p=.88$ ), squat (Figure 6; $\chi^{2}=0.78, p=.38$ ), and LBM (Figure $7 ; \chi^{2}=0.06$, $p=.80)$.

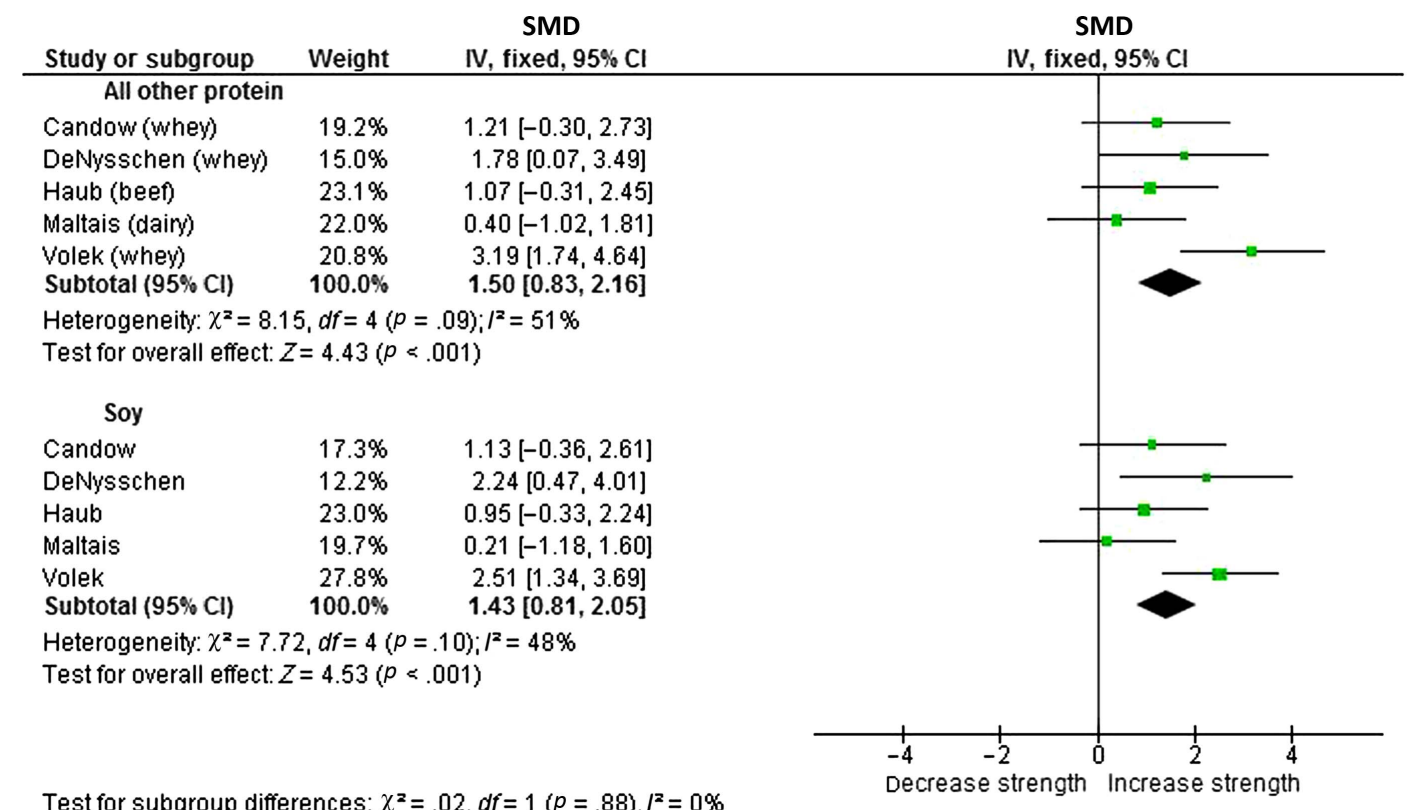

Figure 5 - Forest plot showing the effect of protein source supplementation (other proteins vs. soy) combined with RET, on change (SMD) in bench press strength (one-repetition maximum). Effect for each group and a comparison of change between groups $\left(\chi^{2}\right)$ are shown. RET $=$ resistance exercise training; $\mathrm{SMD}=$ standard mean difference; $\mathrm{CI}=$ confidence interval. 


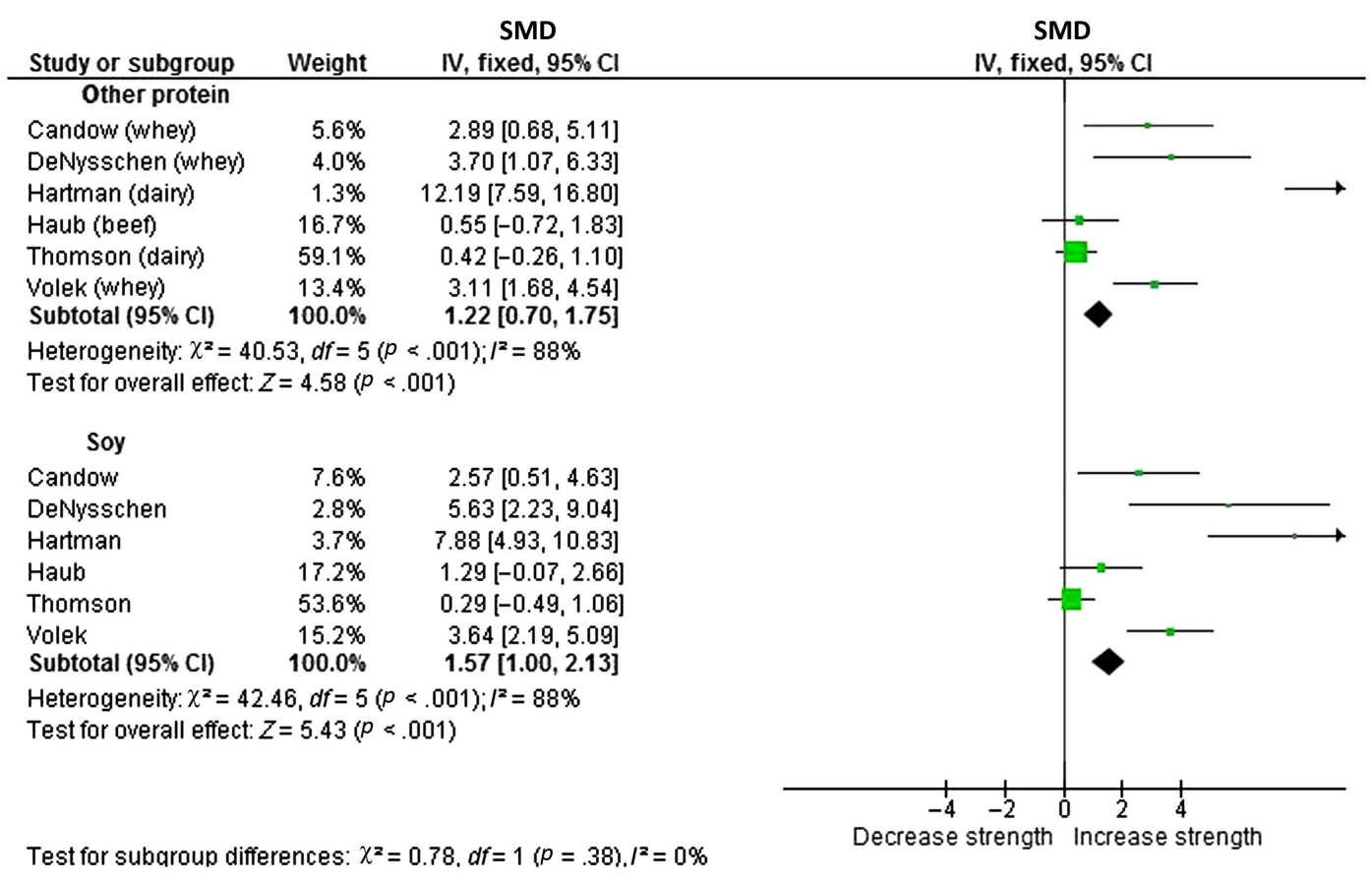

Figure 6 - Forest plot showing the effect of protein source supplementation (other proteins vs. soy) combined with RET, on change (SMD) in squat/leg press strength (one-repetition maximum). Effect for each group and a comparison of change between groups $\left(\chi^{2}\right)$ are shown. RET $=$ resistance exercise training; $\mathrm{SMD}=$ standard mean difference; $\mathrm{CI}=$ confidence interval.

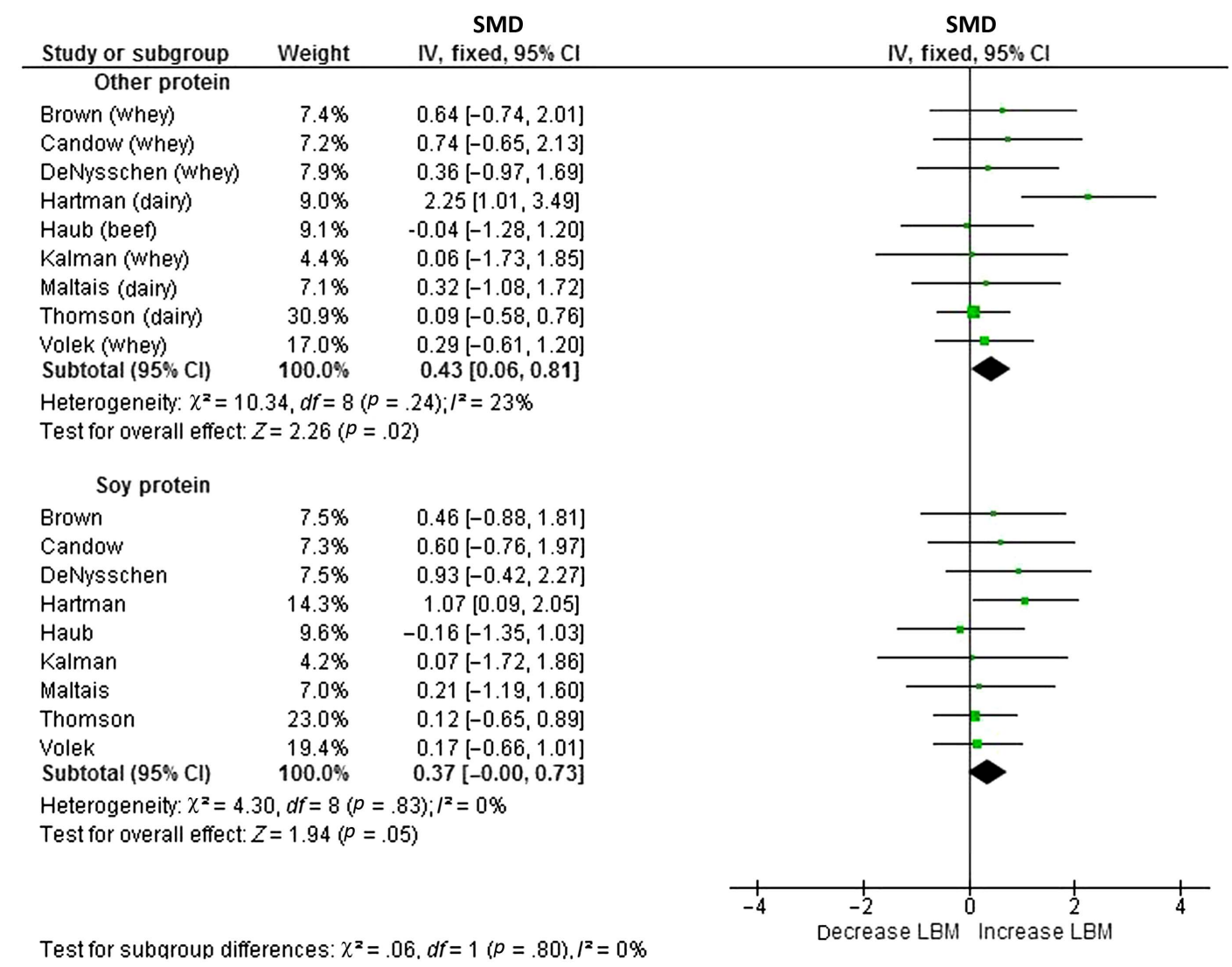

Figure 7 - Forest plot showing the effect of protein source supplementation (other proteins vs. soy) combined with RET, on change (SMD) in LBM. Effect for each group and a comparison of change between groups $\left(\chi^{2}\right)$ are shown. $\mathrm{LBM}=$ lean body mass; RET = resistance exercise training; $\mathrm{SMD}=$ standard mean difference; $\mathrm{CI}=$ confidence interval. 


\section{Discussion}

Acute studies showed that when matched for nitrogen content, soy protein stimulates MPS to a lesser extent than whey protein (Gran et al., 2014; Luiking et al., 2011; Mitchell et al., 2015; Rittig et al., 2017; Tang et al., 2009; Wilkinson et al., 2007; Yang, et al., 2012a), a difference likely mostly due to the lower leucine concentration of the former. Consequently, these differences have led to speculation that soy protein is inferior to milk and whey protein in building muscle and increasing strength in response to RET (Devries \& Phillips, 2015; Jäger et al., 2017). However, the results of the current meta-analysis do not support such speculation as strength (bench press and squat) and lean tissue accretion in response to RET were similar between whey and soy protein supplementation (Brown et al., 2004; Candow et al., 2006; Denysschen et al., 2009; Hartman et al., 2007; Haub et al., 2002; Kalman et al., 2007; Maltais et al., 2016; Thomson et al., 2016; Volek et al., 2013).

To the knowledge of the authors, no previous meta-analysis of studies comparing the effects of soy protein with a control protein on strength and LBM has been published. Nevertheless, for at least two reasons, the results are not surprising. First, gains in strength in response to RET, especially among novice weight lifters who comprised most of the study participants in the meta-analysis, are due to a combination of neurological and morphological factors, not just increases in muscle size (Folland \& Williams, 2007). These factors may not be influenced by protein source or overall protein intake (Reidy et al., 2016). Second, in two of the nine studies included in the meta-analysis, soy protein was compared with milk protein (Hartman et al., 2007; Maltais et al., 2016); and in another study, soy protein was compared with protein from a mix of dairy products (Thomson et al., 2016). Given that dairy protein is comprised of $80 \%$ casein (Mackle et al., 1999) and that soy protein is at least as effective as casein at stimulating MPS in acute studies (Luiking et al., 2011; Tang et al., 2009), there is little reason for soy protein and dairy protein to differentially affect strength or lean tissue accretion. Furthermore, in one of these studies, both the soy and milk groups were supplemented with leucine (Maltais et al., 2016). Therefore, the results of the current meta-analysis are actually consistent with existing understanding of the effect of dietary protein type on strength and lean tissue accretion in response to RET.

The current meta-analysis found that supplementation with whey or soy protein during RET results in similar increases in LBM and strength (Figures 2-4). Although this finding contrasts with the results of acute studies, it is supported by previous work that has shown a lack of correlation between acute changes in MPS and gains in LBM among individuals (Mayhew et al., 2009; Mitchell et al., 2014). It should be noted that many acute studies assess MPS over a 3- to 5-hr postexercise period (Gran et al., 2014; Luiking et al., 2011; Mitchell et al., 2015; Rittig et al., 2017; Tang et al., 2009; Wilkinson et al., 2007; Yang et al., 2012a), whereas MPS can remain elevated for up to 72-hr postexercise (Miller et al., 2005). Consequently, the acute studies may not capture the entire hypertrophic period, and therefore, differences among protein sources on acute MPS may be exaggerated in the early postexercise period. To that end, Damas et al. (2016) recently performed correlational analyses between changes in fiber cross-sectional area after 10 weeks of RET and acute measures of myofibrillar protein synthesis. Importantly, myofibrillar protein synthesis was assessed over a 24-hr time course at three time points during the RET: pretraining, at 3 weeks of training, and at 10 weeks of training. Although Damas et al. (2016) did observe a correlation between fiber cross-sectional area and acute measures of myofibrillar protein synthesis made after 3 and 10 weeks of training, no correlation was observed between acute measures of myofibrillar protein synthesis assessed during the initial exercise session (i.e., pretraining) and fiber crosssectional area after 10 weeks of RET. Consequently, the MPS response to unaccustomed exercise may also make correlational analyses between acute MPS and chronic adaptions more difficult. In addition, muscle hypertrophy is governed by the relationship between protein synthesis and protein breakdown, and often protein breakdown is not assessed or cannot be assessed to the same degree of precision using current techniques. Whether the observed differences in MPS observed between whey and soy protein in acute exercise studies would manifest in different muscle adaptations over a longer RET period than was evaluated in the studies included in the current meta-analysis requires further study.

A recently published meta-analysis by Morton et al. (2017), which included 49 intervention studies involving 1,863 participants, examined the effect of protein supplementation on changes in muscle mass and strength in conjunction with resistance training. The authors found that consumption of protein supplements alongside RET resulted in greater increases in fat-free mass and muscle strength than resistance training alone and that the effect of protein supplementation was more pronounced among trained participants and attenuated with increasing age. In their analysis, Morton et al. (2017) did not distinguish among protein sources, but rather analyzed the effect of protein versus no protein supplementation on effect size.

The meta-regression also conducted by these authors, including 15 studies, which investigated the influence of protein source (soy vs. whey) on change in LBM or strength, concluded it is potentially a very minor determinant (Morton et al., 2017). Metaregression is seen by some authors to be hypothesis generating rather than hypothesis testing (Baker et al., 2009), and thus, the current work sought to further determine the contribution of protein source to change in LBM or strength by conducting meta-analyses using selected studies that compared changes in these parameters in response to supplementing with soy protein versus whey protein and soy protein versus different animal proteins. The studies used in the current analyses were randomized trials, where a soy protein experimental arm was compared with another experimental arm that intervened with a different animal protein. One issue with meta-regression is that potential correlation characteristics among variables may not be adequately identified (Thompson \& Higgins, 2002). Therefore, characteristics that may differ among trials (such as trial duration or protein dose) would be taken into account in the current meta-analyses to a greater extent.

In the current study, two meta-analyses were conducted: one compared soy protein with whey protein (the "gold-standard" protein supplement) and other compared soy protein with all other animal proteins. The present results both confirm the observation by Morton et al. (2017) and extend it by showing differences do not exist not only between soy protein and whey but also between soy protein and animal protein in general.

It is noteworthy that in three of the five studies intervening with whey included in our meta-analysis, the participants were young and untrained (Candow et al., 2006; Denysschen et al., 2009; Volek et al., 2013) and in another (Kalman et al., 2007), the number of trained participants was unclear. Recent data show that protein supplementation following RET is primarily effective only in highly trained individuals. The proposed reason being that the effect of protein supplementation is overwhelmed by the very 
robust response to RET that occurs in novice weight lifters (Morton et al., 2017). This point is supported by a recent 12-week trial involving untrained college-aged males by Mobley et al. (2017), who found that RET led to increases in LBM and strength, but neither whey nor soy protein supplementation affected these changes. Further research is needed to determine more definitively whether protein type affects strength and LBM in highly trained individuals.

The International Society of Sports Nutrition recommends that acute protein doses should contain as much as $3 \mathrm{~g}$ of leucine (Jäger et al., 2017), although the optimal leucine dose depends on factors such as age and body weight (Burd et al., 2013; Moore et al., 2009; Witard et al., 2014). To obtain $3 \mathrm{~g}$ of leucine, $\sim 38 \mathrm{~g}$ of soy protein should be consumed. The results of the current meta-analysis suggest that this upper limit may not be necessary with regard to gains in strength and LBM during RET as only three (Candow et al., 2006; Haub et al., 2002; Kalman et al., 2007) of the nine studies intervened with an amount of soy protein that would have provided $3 \mathrm{~g}$ of leucine. When considering only those studies in which soy protein was compared with whey protein, two studies (Candow et al., 2006; Kalman et al., 2007) provided $\geq 38$ g/day soy protein and three studies (Brown et al., 2004; Denysschen et al., 2009; Volek et al., 2013) provided less than this amount; yet, the meta-analysis showed there were no significant difference between whey and soy protein. Therefore, it would appear lower amounts of leucine than are recommended by the ISSN are capable of facilitating gains in strength and LBM during RET.

One criticism of soy foods as a source of protein for increasing strength and LBM is that the isoflavones naturally present in the soybean will inhibit mTOR activation (Jäger et al., 2017). The isoflavone concentration in traditional Asian soy foods is $\sim 3.5 \mathrm{mg} / \mathrm{g}$ protein, whereas as a result of processing, in most concentrated sources of soy protein, it is much lower $(<1 \mathrm{mg} / \mathrm{g})$ (Messina et al., 2006). Interestingly, two studies have shown that isoflavones do inhibit mTOR (Cederroth et al., 2008; Liu et al., 2015); however, both of these were conducted in mice. In addition to the normal caveats about extrapolating findings from rodents to humans (Liu et al., 2015), mice are a poor model for understanding the effects of isoflavones in humans because these two species metabolize isoflavones so differently ( $\mathrm{Gu}$ et al., 2006; Setchell et al., 2011). Furthermore, in one of the mouse studies (Liu et al., 2015), mice were given $160 \mathrm{mg}$ /day of genistein (the predominant isoflavone in soybeans) per kilogram of body weight. Average genistein intake among native Japanese following a traditional diet is only about $0.3 \mathrm{mg} /$ day per kilogram body weight (Messina et al., 2006). Even when acknowledging the faster metabolism of rodents compared with humans (Reagan-Shaw et al., 2008), the dose used in this study is clearly pharmacological and therefore of questionable relevance (Liu et al., 2015). The results of the current analysis, which show supplementation of soy protein containing isoflavones leads to similar gains in strength and LBM in response to RET as does animal protein, also argues against isoflavones inhibiting muscle growth in response to RET, at least in untrained adult men and women. However, further research is necessary to determine whether similar or different molecular processes are involved.

Finally, it is important to acknowledge the limitations of the data. In particular, we recognize that the studies described in Table 1 varied markedly in experimental design, such as the preintervention training status, age, and gender and often involved very small participant numbers, and for some measures, the statistical comparisons between whey and soy protein were limited to only three studies. Furthermore, the relatively low number of studies and participants who met the criteria for our meta-analysis did not provide appropriate power to identify the independent influence of age or gender on our outcomes. Specifically, there is a particular need for more research focused on the protein needs of older individuals as their leucine requirements are higher, their caloric and protein intake often suboptimal, and many are at risk of developing sarcopenia (Leidy, 2017). Another possible limitation is that the meta-analysis included the study by Maltais et al. (2016) even though as noted, the participants in both the milk and soy groups were supplemented with IAA including leucine. Although we chose to include this study, when it is eliminated from the analysis, the results are not appreciably altered (data not shown).

In conclusion, the current meta-analysis is consistent with the totality of evidence regarding protein supplementation and RET. Our meta-analysis identified that soy foods and soy protein supplements can be viewed as sources of protein suitable for building strength and increasing lean tissue in response to RET. Overall, the results indicate that protein source is not likely an important factor influencing gains in strength and LBM in response to RET. As two dietary principles are moderation and variety, rather than relying on just one source, including soy protein as an option for meeting protein needs for those wanting to increase strength and LBM makes overall nutritional sense. Whether a mix of soy and dairy protein might actually increase strength and LBM relative to a single protein remains to be established (Reidy et al., 2013, 2016).

\section{Acknowledgments}

M. Messina and K. E. Reed conducted the literature search to identify studies for inclusion in the meta-analysis and extracted the necessary data. K. E. Reed conducted the statistical analysis. M. Messina, K. E. Reed, H. Lynch, and J. M. Dickinson participated in the writing of the manuscript and reviewed the literature cited. All authors approved the final version of the paper. K. E. Reed, H. Lynch, and J. M. Dickinson have no conflicts. M. Messina is the executive director of the Soy Nutrition Institute, an organization that is partially funded by the soy industry.

\section{References}

Anthony, J.C., Yoshizawa, F., Anthony, T.G., Vary, T.C., Jefferson, L.S., \& Kimball, S.R. (2000). Leucine stimulates translation initiation in skeletal muscle of postabsorptive rats via a rapamycin-sensitive pathway. Journal of Nutrition, 130, 2413-2419. PubMed ID: 11015466 doi:10.1093/jn/130.10.2413

Baker, W.L., White, C.M., Cappelleri, J.C., Kluger, J., \& Coleman, C.I. (2009). Understanding heterogeneity in meta-analysis: The role of meta-regression. International Journal of Clinical Practice, 63, 1426-1434. PubMed ID: 19769699 doi:10.1111/j.1742-1241.2009. 02168.x

Bolster, D.R., Vary, T.C., Kimball, S.R., \& Jefferson, L.S. (2004). Leucine regulates translation initiation in rat skeletal muscle via enhanced eIF4G phosphorylation. Journal of Nutrition, 134, 1704-1710. PubMed ID: 15226457 doi:10.1093/jn/134.7.1704

Bradlee, M.L., Mustafa, J., Singer, M.R., \& Moore, L.L. (2017). Highprotein foods and physical activity protect against age-related muscle loss and functional decline. The Journals of Gerontology. Series A: Biological Sciences and Medical Sciences, 73, 88-94. doi:10.1093/ gerona/glx070 
Breen, L., \& Phillips, S.M. (2011). Skeletal muscle protein metabolism in the elderly: Interventions to counteract the 'anabolic resistance' of ageing. Nutrition \& Metabolism, 8, 68. doi:10.1186/1743-7075-8-68

Brown, E.C., Disilvestro, R.A., Babaknia, A., \& Devor, S.T. (2004). Soy versus whey protein bars: Effects on exercise training impact on lean body mass and antioxidant status. Nutrition Journal, 3, 22. doi: 10.1186/1475-2891-3-22

Burd, N.A., Gorissen, S.H., \& van Loon, L.J. (2013). Anabolic resistance of muscle protein synthesis with aging. Exercise and Sport Sciences Reviews, 41, 169-173. PubMed ID: 23558692 doi:10.1097/JES. 0b013e318292f3d5

Burd, N.A., West, D.W., Moore, D.R., Atherton, P.J., Staples, A.W., Prior, T., ... Phillips, S.M. (2011). Enhanced amino acid sensitivity of myofibrillar protein synthesis persists for up to $24 \mathrm{~h}$ after resistance exercise in young men. Journal of Nutrition, 141, 568-573. PubMed ID: 21289204 doi:10.3945/jn.110.135038

Candow, D.G., Burke, N.C., Smith-Palmer, T., \& Burke, D.G. (2006). Effect of whey and soy protein supplementation combined with resistance training in young adults. International Journal of Sport Nutrition and Exercise Metabolism, 16, 233-244. PubMed ID: 16948480 doi:10.1123/ijsnem.16.3.233

Cederroth, C.R., Vinciguerra, M., Gjinovci, A., Kuhne, F., Klein, M., Cederroth, M., ... Nef, S. (2008). Dietary phytoestrogens activate AMP-activated protein kinase with improvement in lipid and glucose metabolism. Diabetes, 57, 1176-1185. PubMed ID: 18420492 doi: $10.2337 / \mathrm{db} 07-0630$

Churchward-Venne, T.A., Breen, L., Di Donato, D.M., Hector, A.J., Mitchell, C.J., Moore, D.R., ... Phillips, S.M. (2014). Leucine supplementation of a low-protein mixed macronutrient beverage enhances myofibrillar protein synthesis in young men: A doubleblind, randomized trial. The American Journal of Clinical Nutrition, 99, 276-286. PubMed ID: 24284442 doi:10.3945/ajcn.113.068775

Cuenca-Sanchez, M., Navas-Carrillo, D., \& Orenes-Pinero, E. (2015). Controversies surrounding high-protein diet intake: Satiating effect and kidney and bone health. Advances in Nutrition, 6, 260-266. PubMed ID: 25979491 doi:10.3945/an.114.007716

Damas, F., Phillips, S.M., Libardi, C.A., Vechin, F.C., Lixandrao, M.E., Jannig, P.R., ... Ugrinowitsch, C. (2016). Resistance traininginduced changes in integrated myofibrillar protein synthesis are related to hypertrophy only after attenuation of muscle damage. The Journal of Physiology, 594, 5209-5222. PubMed ID: 27219125 doi:10.1113/JP272472

Denysschen, C.A., Burton, H.W., Horvath, P.J., Leddy, J.J., \& Browne, R.W. (2009). Resistance training with soy vs. whey protein supplements in hyperlipidemic males. Journal of the International Society of Sports Nutrition, 6, 8. doi:10.1186/1550-2783-6-8

Devries, M.C., \& Phillips, S.M. (2015). Supplemental protein in support of muscle mass and health: Advantage whey. Journal of Food Science, 80(Suppl. 1), A8-A15. doi:10.1111/1750-3841.12802

D’Souza, R.F., Marworth, J.F., Figueiredo, V.C., Della Gatta, P.A., Petersen, A.C., Mitchell, C.J., \& Cameron-Smith, D. (2014). Dose-dependent increases in p70S6K phosphorylation and intramuscular branched-chain amino acids in older men following resistance exercise and protein intake. Physiological Reports, 2(8), e12112. doi:10.14814/phy2.12112

Folland, J.P., \& Williams, A.G. (2007). The adaptations to strength training: Morphological and neurological contributions to increased strength. Sports Medicine, 37, 145-168. PubMed ID: 17241104 doi:10.2165/00007256-200737020-00004

Fouillet, H., Mariotti, F., Gaudichon, C., Bos, C., \& Tome, D. (2002). Peripheral and splanchnic metabolism of dietary nitrogen are differently affected by the protein source in humans as assessed by compartmental modeling. Journal of Nutrition, 132, 125-133. PubMed ID: 11773519 doi:10.1093/jn/132.1.125

Glynn, E.L., Fry, C.S., Drummond, M.J., Timmerman, K.L., Dhanani, S., Volpi, E., \& Rasmussen, B.B. (2010). Excess leucine intake enhances muscle anabolic signaling but not net protein anabolism in young men and women. Journal of Nutrition, 140, 1970-1976. PubMed ID: 20844186 doi:10.3945/jn.110.127647

Gran, P., Larsen, A.E., Bonham, M., Dordevic, A.L., Rupasinghe, T., Silva, C., ... Cameron-Smith, D. (2014). Muscle p70S6K phosphorylation in response to soy and dairy rich meals in middle aged men with metabolic syndrome: A randomised crossover trial. Nutrition \& Metabolism, 11, 46. doi:10.1186/1743-7075-11-46

Gu, L., House, S.E., Prior, R.L., Fang, N., Ronis, M.J., Clarkson, T.B., . . . Badger, T.M. (2006). Metabolic phenotype of isoflavones differ among female rats, pigs, monkeys, and women. Journal of Nutrition, 136, 1215-1221. PubMed ID: 16614407 doi:10.1093/jn/136.5. 1215

Hartman, J.W., Tang, J.E., Wilkinson, S.B., Tarnopolsky, M.A., Lawrence, R.L., Fullerton, A.V., \& Phillips, S.M. (2007). Consumption of fatfree fluid milk after resistance exercise promotes greater lean mass accretion than does consumption of soy or carbohydrate in young, novice, male weightlifters. The American Journal of Clinical Nutrition, 86, 373-381. PubMed ID: 17684208 doi:10.1093/ajcn/ 86.2.373

Haub, M.D., Wells, A.M., Tarnopolsky, M.A., \& Campbell, W.W. (2002). Effect of protein source on resistive-training-induced changes in body composition and muscle size in older men. The American Journal of Clinical Nutrition, 76, 511-517. PubMed ID: 12197993 doi:10.1093/ ajen/76.3.511

Hughes, G.J., Ryan, D.J., Mukherjea, R., \& Schasteen, C.S. (2011). Protein digestibility-corrected amino acid scores (PDCAAS) for soy protein isolates and concentrate: Criteria for evaluation. Journal of Agricultural and Food Chemistry, 59, 12707-12712. PubMed ID: 22017752 doi:10.1021/jf203220v

Hulmi, J.J., Lockwood, C.M., \& Stout, J.R. (2010). Effect of protein/ essential amino acids and resistance training on skeletal muscle hypertrophy: A case for whey protein. Nutrition \& Metabolism, 7, 51. doi:10.1186/1743-7075-7-51

Jäger, R., Kerksick, C.M., Campbell, B.I., Cribb, P.J., Wells, S.D., Skwiat, T.M., ... Antonio, J. (2017). International society of sports nutrition position stand: Protein and exercise. Journal of the International Society of Sports Nutrition, 14, 1-25. doi:10.1186/s12970-017-0177-8

Kalman, D., Feldman, S., Martinez, M., Krieger, D.R., \& Tallon, M.J. (2007). Effect of protein source and resistance training on body composition and sex hormones. Journal of the International Society of Sports Nutrition, 4, 4. doi:10.1186/1550-2783-4-4

Katsanos, C.S., Kobayashi, H., Sheffield-Moore, M., Aarsland, A., \& Wolfe, R.R. (2006). A high proportion of leucine is required for optimal stimulation of the rate of muscle protein synthesis by essential amino acids in the elderly. American Journal of PhysiologyEndocrinology and Metabolism, 291, E381-E387. doi:10.1152/ ajpendo.00488.2005

Leidy, H.J. (2017). Consumption of protein beverages as a strategy to promote increased energy intake in older adults. The American Journal of Clinical Nutrition, 106, 715-716. PubMed ID: 28793986

Li, R., Xia, J., Zhang, X., Gathirua-Mwangi, W.G., Guo, J., Li, Y., ... Song, Y. (2018). Associations of muscle mass and strength with allcause mortality among US older adults. Medicine \& Science in Sports \& Exercise, 50(3), 458-467. doi:10.1249/MSS.0000000000001448

Liu, M., Qi, Z., Liu, B., Ren, Y., Li, H., Yang, G., \& Zhang, Q. (2015). $\mathrm{RY}-2 \mathrm{f}$, an isoflavone analog, overcomes cisplatin resistance to inhibit ovarian tumorigenesis via targeting the PI3K/AKT/mTOR 
signaling pathway. Oncotarget, 6, 25281-25294. PubMed ID: 26325371

Luiking, Y.C., Deutz, N.E., Jakel, M., \& Soeters, P.B. (2005). Casein and soy protein meals differentially affect whole-body and splanchnic protein metabolism in healthy humans. Journal of Nutrition, 135, 1080-1087. PubMed ID: 15867285 doi:10.1093/jn/135.5.1080

Luiking, Y.C., Engelen, M.P., Soeters, P.B., Boirie, Y., \& Deutz, N.E. (2011). Differential metabolic effects of casein and soy protein meals on skeletal muscle in healthy volunteers. Clinical Nutrition, 30, 65-72. PubMed ID: 20685015 doi:10.1016/j.clnu.2010.06.012

Mackle, T.R., Bryant, A.M., Petch, S.F., Hooper, R.J., \& Auldist, M.J. (1999). Variation in the composition of milk protein from pasture-fed dairy cows in late lactation and the effect of grain and silage supplementation. New Zealand Journal of Agricultural Research, 42, 147-154. doi:10.1080/00288233.1999.9513364

Maltais, M.L., Ladouceur, J.P., \& Dionne, I.J. (2016). The effect of resistance training and different sources of postexercise protein supplementation on muscle mass and physical capacity in sarcopenic elderly men. The Journal of Strength and Conditioning Research, 30, 1680-1687. PubMed ID: 26562709 doi:10.1519/JSC. 0000000000001255

Mayhew, D.L., Kim, J.S., Cross, J.M., Ferrando, A.A., \& Bamman, M.M. (2009). Translational signaling responses preceding resistance training-mediated myofiber hypertrophy in young and old humans. Journal of Applied Physiology, 107, 1655-1662. PubMed ID: 19589955 doi:10.1152/japplphysiol.91234.2008

Messina, M., Nagata, C., \& Wu, A.H. (2006). Estimated Asian adult soy protein and isoflavone intakes. Nutrition and Cancer, 55, 1-12. PubMed ID: 16965235 doi:10.1207/s15327914nc5501_1

Messina, M.J. (1999). Legumes and soybeans: Overview of their nutritional profiles and health effects. The American Journal of Clinical Nutrition, 70, 439S-450S. PubMed ID: 10479216 doi:10.1093/ajcn/ 70.3.439s

Miller, B.F., Olesen, J.L., Hansen, M., Døssing, S., Crameri, R.M., Welling, R.J., ... Rennie, M.J. (2005). Coordinated collagen and muscle protein synthesis in human patella tendon and quadriceps muscle after exercise. The Journal of Physiology, 567, 1021-1033. PubMed ID: 16002437 doi:10.1113/jphysiol.2005.093690

Mitchell, C.J., Churchward-Venne, T.A., Parise, G., Bellamy, L., Baker, S.K., Smith, K., . . P Phillips, S.M. (2014). Acute post-exercise myofibrillar protein synthesis is not correlated with resistance training-induced muscle hypertrophy in young men. PLoS ONE, 9, e89431. PubMed ID: 24586775 doi:10.1371/journal.pone. 0089431

Mitchell, C.J., Della Gatta, P.A., Petersen, A.C., Cameron-Smith, D., \& Markworth, J.F. (2015). Soy protein ingestion results in less prolonged p70S6 kinase phosphorylation compared to whey protein after resistance exercise in older men. Journal of the International Society of Sports Nutrition, 12, 6. doi:10.1186/s12970-015-0070-2

Mobley, C.B., Haun, C.T., Roberson, P.A., Mumford, P.W., Romero, M.A., Kephart, W.C., . . Roberts, M.D. (2017). Effects of whey, soy or leucine supplementation with 12 weeks of resistance training on strength, body composition, and skeletal muscle and adipose tissue histological attributes in college-aged males. Nutrients, 9(9), 972. PubMed ID: 28869573 doi:10.3390/nu9090972

Moher, D., Liberati, A., Tetzlaff, J., \& Altman, D.G. (2009). Preferred reporting items for systematic reviews and meta-analyses: The PRISMA statement. British Medical Journal, 151(4), 264-269.

Moore, D.R., Churchward-Venne, T.A., Witard, O., Breen, L., Burd, N.A., Tipton, K.D., \& Phillips, S.M. (2015). Protein ingestion to stimulate myofibrillar protein synthesis requires greater relative protein intakes in healthy older versus younger men. The Journals of Gerontology.
Series A: Biological Sciences and Medical Sciences, 70, 57-62. doi:10.1093/gerona/glu103

Moore, D.R., Robinson, M.J., Fry, J.L., Tang, J.E., Glover, E.I., Wilkinson, S.B., Prior, T., .. P Phillips, S.M. (2009). Ingested protein dose response of muscle and albumin protein synthesis after resistance exercise in young men. The American Journal of Clinical Nutrition, 89, 161-168. PubMed ID: 19056590 doi:10.3945/ajcn.2008.26401

Morton, R.W., Murphy, K.T., McKellar, S.R., Schoenfeld, B.J., Henselmans, M., Helms, E., ... Phillips, S.M. (2017). A systematic review, meta-analysis and meta-regression of the effect of protein supplementation on resistance training-induced gains in muscle mass and strength in healthy adults. British Journal of Sports Medicine, 52, 376-384. PubMed ID: 28698222

Newman, A.B., Kupelian, V., Visser, M., Simonsick, E.M., Goodpaster, B.H., Kritchevsky, S.B., ... Harris, T.B. (2006). Strength, but not muscle mass, is associated with mortality in the health, aging and body composition study cohort. The Journals of Gerontology. Series A: Biological Sciences and Medical Sciences, 61, 72-77. doi: 10.1093/gerona/61.1.72

Norton, L.E., Wilson, G.J., Layman, D.K., Moulton, C.J., \& Garlick, P.J. (2012). Leucine content of dietary proteins is a determinant of postprandial skeletal muscle protein synthesis in adult rats. Nutrition \& Metabolism, 9, 67. doi:10.1186/1743-7075-9-67

Phillips, S.M. (2014). A brief review of critical processes in exerciseinduced muscular hypertrophy. Sports Medicine, 44(Suppl. 1), S71-S77. doi:10.1007/s40279-014-0152-3

Reagan-Shaw, S., Nihal, M., \& Ahmad, N. (2008). Dose translation from animal to human studies revisited. The FASEB Journal, 22, 659-661. PubMed ID: 17942826 doi:10.1096/fj.07-9574LSF

Reidy, P.T., Borack, M.S., Markofski, M.M., Dickinson, J.M., Deer, R.R., Husaini, S.H., . . R Rasmussen, B.B. (2016). Protein supplementation has minimal effects on muscle adaptations during resistance exercise training in young men: A double-blind randomized clinical trial. Journal of Nutrition, 146, 1660-1669. PubMed ID: 27466602 doi: 10.3945/jn.116.231803

Reidy, P.T., Walker, D.K., Dickinson, J.M., Gundermann, D.M., Drummond, M.J., Timmerman, K.L., .. Rasmussen, B.B. (2013). Protein blend ingestion following resistance exercise promotes human muscle protein synthesis. Journal of Nutrition, 143, 410 416. PubMed ID: 23343671 doi:10.3945/jn.112.168021

Richter, C.K., Skulas-Ray, A.C., Champagne, C.M., \& Kris-Etherton, P.M. (2015). Plant protein and animal proteins: Do they differentially affect cardiovascular disease risk? Advances in Nutrition, 6, 712-728. PubMed ID: 26567196 doi:10.3945/an.115.009654

Rittig, N., Bach, E., Thomsen, H.H., Moller, A.B., Hansen, J., Johannsen, M., ... Moller, N. (2017). Anabolic effects of leucine-rich whey protein, carbohydrate, and soy protein with and without $\beta$-hydroxy- $\beta$ methylbutyrate (HMB) during fasting-induced catabolism: A human randomized crossover trial. Clinical Nutrition, 36, 697-705. PubMed ID: 27265181 doi:10.1016/j.clnu.2016.05.004

Rizzo, N.S., Jaceldo-Siegl, K., Sabate, J., \& Fraser, G.E. (2013). Nutrient profiles of vegetarian and nonvegetarian dietary patterns. Journal of the Academy of Nutrition and Dietetics, 113, 1610-1619. doi: 10.1016/j.jand.2013.06.349

Rutherfurd, S.M., Fanning, A.C., Miller, B.J., \& Moughan, P.J. (2015). Protein digestibility-corrected amino acid scores and digestible indispensable amino acid scores differentially describe protein quality in growing male rats. Journal of Nutrition, 145, 372-379. PubMed ID: 25644361 doi:10.3945/jn.114.195438

Setchell, K.D., Brown, N.M., Zhao, X., Lindley, S.L., Heubi, J.E., King, E.C., \& Messina, M.J. (2011). Soy isoflavone phase II metabolism differs between rodents and humans: Implications for the effect on 
breast cancer risk. The American Journal of Clinical Nutrition, 94, 1284-1294. PubMed ID: 21955647 doi:10.3945/ajen.111.019638

Shang, X., Scott, D., Hodge, A., English, D.R., Giles, G.G., Ebeling, P.R., \& Sanders, K.M. (2016a). Dietary protein from different food sources, incident metabolic syndrome and changes in its components: An 11-year longitudinal study in healthy community-dwelling adults. Clinical Nutrition, 36(6):1540-1548. doi:10.1016/j.clnu.2016.09.024

Shang, X., Scott, D., Hodge, A.M., English, D.R., Giles, G.G., Ebeling, P.R., \& Sanders, K.M. (2016b). Dietary protein intake and risk of type 2 diabetes: Results from the Melbourne collaborative cohort study and a meta-analysis of prospective studies. The American Journal of Clinical Nutrition, 104, 1352-1365. doi:10.3945/ajen.116.140954

Shi, M., Bai, J.-F., Seale, J.W., \& Wahl, T.I. (2015). Demographics, societal aging, and meat consumption in China. Journal of Integrative Agriculture, 14, 995-1007.

Speedy, A.W. (2003). Global production and consumption of animal source foods. Journal of Nutrition, 133, 4048S-4053S. PubMed ID: 14672310 doi:10.1093/jn/133.11.4048S

Springmann, M., Godfray, H.C., Rayner, M., \& Scarborough, P. (2016). Analysis and valuation of the health and climate change cobenefits of dietary change. Proceedings of the National Academy of Sciences of the United States of America, 113, 4146-4151. PubMed ID: 27001851 doi:10.1073/pnas.1523119113

Sucher, S., Markova, M., Hornemann, S., Pivovarova, O., Rudovich, N., Thomann, R., ... Pfeiffer, A.F. (2017). A comparison of the effects of diets high in animal or plant protein on metabolic and cardiovascular markers in type 2 diabetes - A randomized clinical trial. Diabetes, Obesity and Metabolism, 19, 944-952. PubMed ID: 28181738 doi:10.1111/dom.12901

Tang, J.E., Moore, D.R., Kujbida, G.W., Tarnopolsky, M.A., \& Phillips, S.M. (2009). Ingestion of whey hydrolysate, casein, or soy protein isolate: Effects on mixed muscle protein synthesis at rest and following resistance exercise in young men. Journal of Applied Physiology, 107, 987-992. PubMed ID: 19589961 doi:10.1152/japplphysiol. 00076.2009

Thompson, S.G., \& Higgins, J.P. (2002). How should meta-regression analyses be undertaken and interpreted? Statistics in Medicine, 21, 1559-1573. PubMed ID: 12111920 doi:10.1002/sim.1187

Thomson, R.L., Brinkworth, G.D., Noakes, M., \& Buckley, J.D. (2016). Muscle strength gains during resistance exercise training are attenuated with soy compared with dairy or usual protein intake in older adults: A randomized controlled trial. Clinical Nutrition, 35, 27-33. PubMed ID: 25702958 doi:10.1016/j.clnu.2015.01.018

Tokede, O.A., Onabanjo, T.A., Yansane, A., Gaziano, J.M., \& Djousse, L. (2015). Soya products and serum lipids: A meta-analysis of randomised controlled trials. British Journal of Nutrition, 114, 831-843. PubMed ID: 26268987 doi:10.1017/S0007114515002603 van Vliet, S., Burd, N.A., \& van Loon, L.J. (2015). The skeletal muscle anabolic response to plant- versus animal-based protein consumption. Journal of Nutrition, 145, 1981-1991. PubMed ID: 26224750 doi: 10.3945/jn.114.204305

Volek, J.S., Volk, B.M., Gomez, A.L., Kunces, L.J., Kupchak, B.R., Freidenreich, D.J., ... Kraemer, W.J. (2013). Whey protein supplementation during resistance training augments lean body mass. Journal of the American College of Nutrition, 32, 122-135. PubMed ID: 24015719 doi:10.1080/07315724.2013.793580

Volpi, E., Mittendorfer, B., Wolf, S.E., \& Wolfe, R.R. (1999). Oral amino acids stimulate muscle protein anabolism in the elderly despite higher first-pass splanchnic extraction. American Journal of Physiology, 277, E513-E520. PubMed ID: 10484364

Wilkinson, D.J., Hossain, T., Hill, D.S., Phillips, B.E., Crossland, H., Williams, J., ... Atherton, P.J. (2013). Effects of leucine and its metabolite beta-hydroxy-beta-methylbutyrate on human skeletal muscle protein metabolism. The Journal of Physiology, 591, 2911-2923. PubMed ID: 23551944 doi:10.1113/jphysiol.2013.253203

Wilkinson, S.B., Tarnopolsky, M.A., Macdonald, M.J., Macdonald, J.R., Armstrong, D., \& Phillips, S.M. (2007). Consumption of fluid skim milk promotes greater muscle protein accretion after resistance exercise than does consumption of an isonitrogenous and isoenergetic soy-protein beverage. The American Journal of Clinical Nutrition, 85, 1031-1040. PubMed ID: 17413102 doi:10.1093/ajen/85.4. 1031

Witard, O.C., Jackman, S.R., Breen, L., Smith, K., Selby, A., \& Tipton, K.D. (2014). Myofibrillar muscle protein synthesis rates subsequent to a meal in response to increasing doses of whey protein at rest and after resistance exercise. The American Journal of Clinical Nutrition, 99, 86-95. PubMed ID: 24257722 doi:10.3945/ajcn. 112.055517

Wolfe, R.R., Cifelli, A.M., Kostas, G., \& Kim, I.Y. (2017). Optimizing protein intake in adults: Interpretation and application of the recommended dietary allowance compared with the acceptable macronutrient distribution range. Advances in Nutrition, 8, 266-275. PubMed ID: 28298271 doi:10.3945/an.116.013821

Yang, Y., Breen, L., Burd, N.A., Hector, A.J., Churchward-Venne, T.A., Josse, A.R., . . Phillips, S.M. (2012a). Resistance exercise enhances myofibrillar protein synthesis with graded intakes of whey protein in older men. British Journal of Nutrition, 108, 1780-1788. doi:10. 1017/S0007114511007422

Yang, Y., Churchward-Venne, T.A., Burd, N.A., Breen, L., Tarnopolsky, M.A., \& Phillips, S.M. (2012b). Myofibrillar protein synthesis following ingestion of soy protein isolate at rest and after resistance exercise in elderly men. Nutrition \& Metabolism, 9, 57. doi:10.1186/ $1743-7075-9-57$ 